Transnational Business Governance Interactions Project Working Paper No. 31

June 2018

\title{
A Coxian Perspective on Transnational Business Governance Interactions: Counter-Hegemonic Certification Movements in Fisheries
}

\author{
Paul Foley \\ Memorial University of Newfoundland
}

This paper is available free of charge from www.tgiforum.org

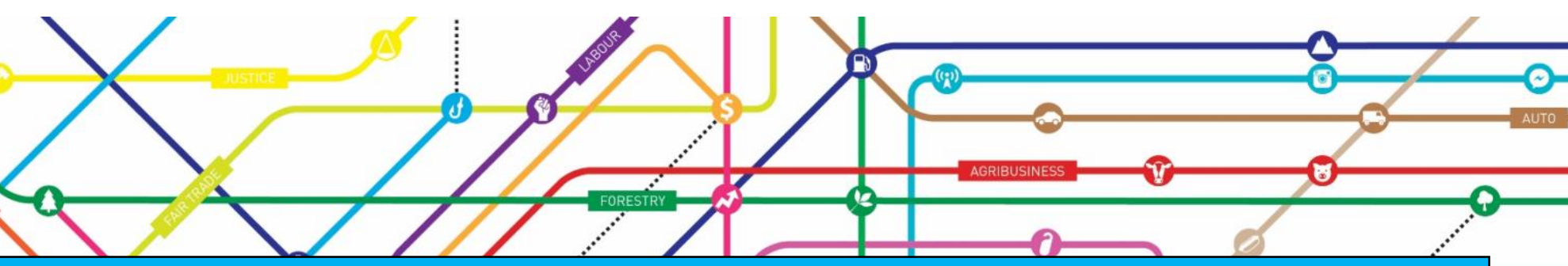

The TBGI Project: Transnational initiatives to regulate business activities interact increasingly with each other and with official regulation, generating complex governance ensembles. Heterogeneous actors and institutions interact at multiple levels and in various ways, from mimicry and cooperation to competition and conflict. The TBGI Project investigates the forms, drivers, mechanisms, dynamics, outputs and impacts of transnational business governance interactions (TBGI) from diverse theoretical and methodological perspectives. It is led by Stepan Wood, Professor and Canada Research Chair in Law, Society and Sustainability at the Peter A. Allard School of Law, University of British Columbia.

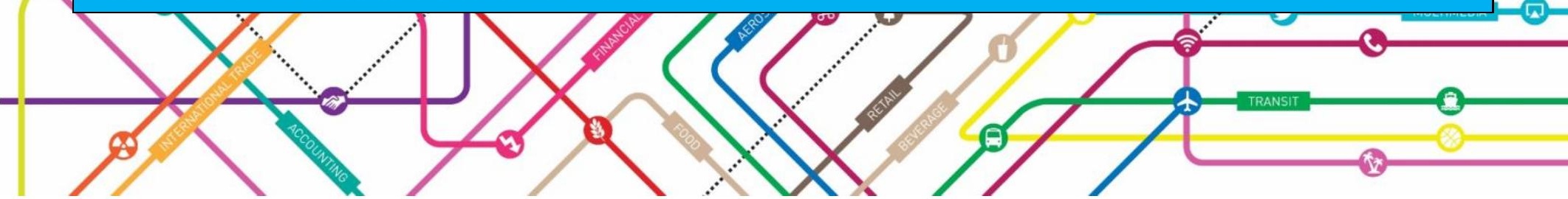




\title{
A Coxian Perspective on Transnational Business Governance Interactions: Counter-Hegemonic Certification Movements in Fisheries
}

\author{
Paul Foley ${ }^{1}$
}

\begin{abstract}
How can under-theorized dimensions of production and social development be integrated into the TBGI analytical project? This chapter addresses this question by applying Robert Cox's 'production and power' approach to an analysis of the global capture fisheries sector. It uses Cox's approach-which emphasizes interactions among social forces of production, state-civil society complexes, and world order-to analyze the creation of alternatives to Marine Stewardship Council (MSC) eco-certification. Producer-oriented alternatives generally seek to integrate ideas and institutions connected to social forces of production, state-civil society complexes, and world order. While this integrated approach to fostering legitimacy and credibility in the global political economy of seafood is common across initiatives, including the MSC, alternatives differ by emphasizing either territorial approaches that privilege producers within particular jurisdictions, or ethical approaches that privilege the social relations of structurally weaker producers. While fledgling ethical eco-certification initiatives have potential to support alternative models of governance and development that empower structurally disadvantaged producers, the counter-hegemonic potential of these alternatives is currently weak.
\end{abstract}

\section{Key words}

Sustainable development, political economy, certification, Marine Stewardship Council, fair trade, neoGramscian

\section{Introduction}

This chapter contributes to the study of Transnational Business Governance Interactions (TBGI) by focusing on the role and interests of producers in patterns of proliferation and competition in transnational governance. Such patterns are widespread in sectors such as coffee (Raynolds and Wilkinson, 2007; Raynolds et al, 2007), forestry (Cashore, Auld and Newsom 2004; Gale 2014), aquaculture (Havice and lles 2015), and fisheries (Foley and Havice 2016). Proliferation and competition are a core focus of the TBGI research agenda but questions remain in terms of how and why competition has emerged in some sectors and not in others and the causes and consequences of competition (Smith and Fischlein 2010; Büthe 2010: 15; Auld 2014; Eberlein et al. 2014). This chapter suggests that new insight can be gained by utilizing a 'production and power' perspective to analyze Transnational Business Governance (TBG) proliferation and competition. The target of most TBG initiatives are producers (Büthe

\footnotetext{
${ }^{1}$ Assistant Professor, Memorial University of Newfoundland, Grenfell Campus. pfoley@grenfell.mun.ca. A revised version of this paper is forthcoming in Stepan Wood et al., eds. Transnational Business Governance Interactions: Empowering Marginalized Actors and Enhancing Regulatory Quality. Cheltenham, UK: Edward Elgar.
} 
2010), but implications for producers and social development are not well understood or theorized (Bartley et al. 2015). While some TBG initiatives have yielded notable achievements, researchers have raised fundamental questions about their impacts for producer livelihoods, empowerment, and local development (Utting 2012; Reed and Mukherjee-Reed 2012). This chapter puts questions of production, power and social development at the forefront. It proposes that we conceptualize the interactive dynamics of TBG in terms of the inter-relations between production and power, including how principles and relations of production and development interact with governance institutions at state and international levels.

This chapter examines the relationship between TBGI and producers by utilizing the critical International Political Economy (IPE) approach to 'production and power' developed by Robert Cox, a pioneer in the development of neo-Gramscian International Relations (IR) scholarship and a novel perspective on hegemony in IR. Unlike conventional IR theory, which reduces hegemony to a single dimension of dominance based on the economic and military capabilities of states, Cox's critical theory broadens the inquiry to include the "basic processes at work in the development of social forces [of production] and forms of state, and in the structure of global political economy" (Cox 1996: 91). Hegemony is understood not as the dominance of one powerful nation state, but as a socialization process with material, cultural and ideological dimensions. Cox's approach is useful because it theorizes not only production and power but also the interactions between transnational governance and the social relations of production in efforts to foster hegemony in the global political economy:

This means starting at the beginning with production so as to consider how the diversity of ways in which production is carried on and the variety of social relationships generated in production processes condition the social forces that can become bases of power in state and world order. It also means following the reverse course to consider how power institutionalized in world order and in the state shapes and controls the development of production relations (Cox, 1987: 4).

This chapter applies Cox's approach to the study of proliferating certification systems in the global capture fisheries sector. As Auld suggests in a study of the Marine Stewardship Council (MSC), "...it is critical to assess the MSC in relation to other fisheries' governance instruments and that efforts are undertaken to enhance attention to the needs of small and marginalized fishers, particularly if development goals are to be advanced" (Auld 2012: 148; see also Auld and Cashore 2013: 154). The chapter argues that the MSC's lack of engagement with and support of political economies of production and development facilitated the emergence of two forms of producer-oriented counter-hegemonic movements, conceptualized below as territorial and ethical eco-certification initiatives.

The next section introduces Cox's approach. Section 3 uses this approach to examine factors that facilitated the emergence of alternatives to MSC. The fourth and fifth sections examine prominent examples of territorial and ethical eco-certification initiatives, emphasizing how principles and relations of production and development interact with governance institutions at state and international levels. Section 6 reflects on the implications of the analysis for TBGI. The conclusion considers the extent to which competing visions of eco-certification in the fisheries sector contain counter-hegemonic potential.

\section{The Approach: Applying Coxian IPE to the study of TBGI}

The TBGI literature advocates for the development of middle-range theoretical tools that can accommodate the multiplicity of interacting entities and scales of interaction, and the co-evolution of social agency and structure (Wood et al. 2015). Robert Cox developed a middle-range method of historical structure as a conceptual tool and heuristic device designed around three interacting spheres of activity and interaction on which hegemony is built: the social relations of production, which more specifically 
refer to the social forces that are generated by the production process; forms of state, which are historically contingent state-civil society complexes; and world orders, consisting of the particular assemblage of forces that sequentially define phases of stability or conflict for the state system (Cox 1996: 135-138).

Figure 1. The Coxian Approach to Historical Structures and its Application to Eco-Certification

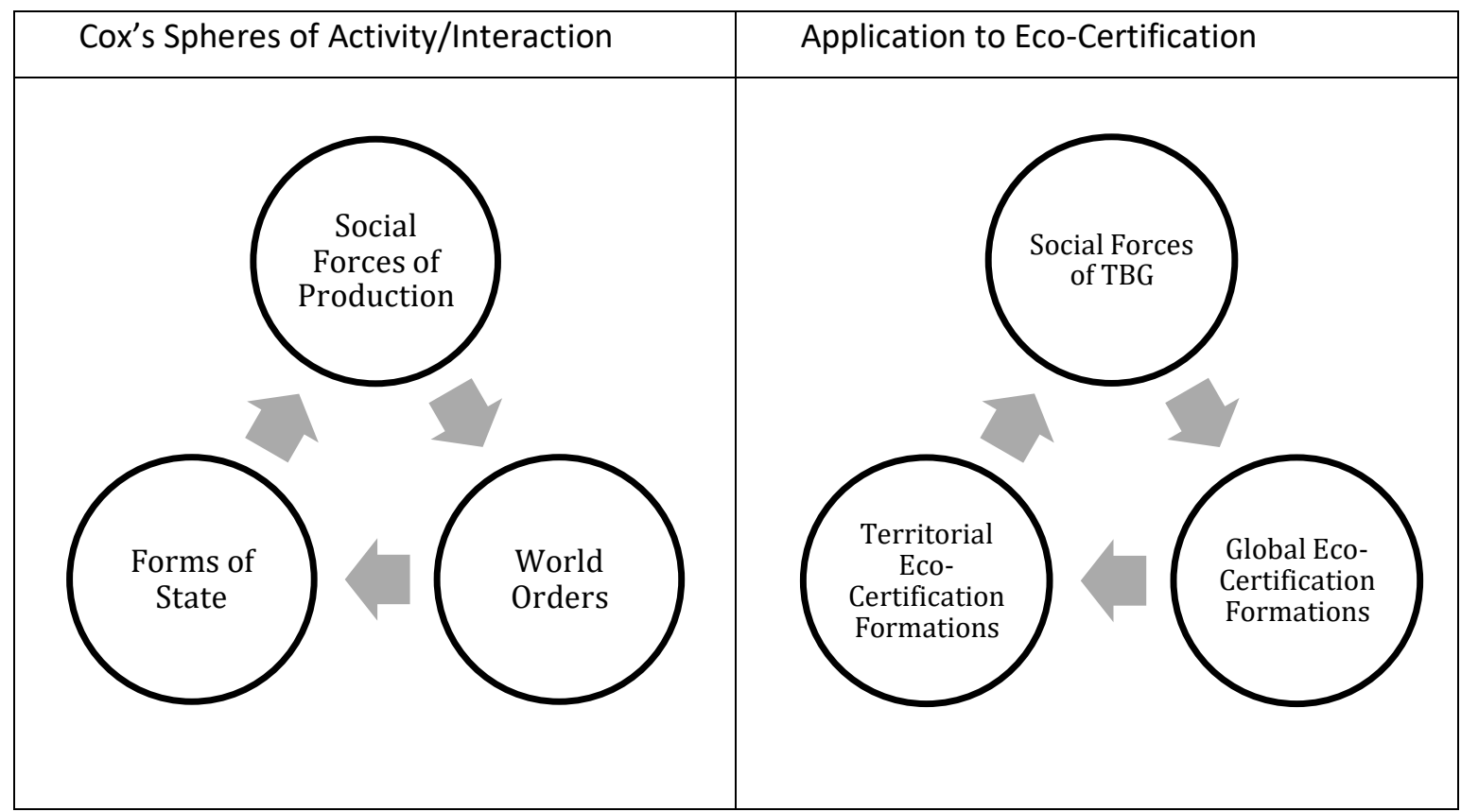

Source: Adapted from Cox 1987, 1996

Within each sphere, three further categories of power interact: material capabilities, ideas (of which there are two kinds), and institutions. Material capabilities refer to productive and destructive power potentials, such as technological and organizational capabilities (Cox 2002: 98). The first type of ideas consists of intersubjective meanings, defined by Cox as "those shared notions of the nature of social relations which tend to perpetuate habits and expectations of behavior," while the second kind of ideas are collective images of social order held by different groups. This includes collective views as to what constitutes the legitimacy of prevailing power relations and the meaning of justice. Institutions are the means through which a particular order is stabilized and perpetuated (Cox 2002: 99).

This approach can be adapted to TBGI research. As illustrated in Figure $1,{ }^{1}$ the sphere of social forces of production can be translated into the social forces of production in TBG eco-certification formations, such as the various social forces that facilitate and regulate the production process. The sphere of forms of state can be translated into national and sub-national, or territorial, eco-certification formations. The world order level of activity can be translated into transnational or global eco-certification formations, including formal transnational certification initiatives (e.g. MSC and ethical eco-certification initiatives) as well as the broader ideas and institutions in which these are embedded. It is important to note that this framework does not imply that actual eco-certification initiatives exist isolated within one of the three spheres. The spheres interact and are mutually constitutive. Actual eco-certification initiatives, this heuristic framework suggests, will tend to interact with and integrate ideas and institutions of the other spheres of activity/interaction. 
Each sphere is, in turn, shaped by the interaction of categories of power: ideas, material capabilities, and institutions. In the eco-certification context, these include 1) the near-hegemonic commitment by various social forces (e.g. various corporations, environmental NGOs, and small-scale producers) to ideas of good governance, transparency, sustainability, and market mechanisms; 2) the material, technological, organizational, and wealth resource capacity for developing knowledge and strategies for assessing production, changing practices, and reorganizing supply chains; and 3) the institutions of multi-stakeholder collaboration, and the tools and techniques of standardization, certification, traceability, labeling, and branding.

The degree to which actual eco-certification initiatives reflect the ideas, interests and material capabilities associated with particular spheres of activity will depend on the interactions among the forces of power. For example, in the cases below, including the MSC and alternatives, all eco-certification initiatives integrate specific production-focused standards (institutions) defined by specific ideas (principles) of sustainable or responsible fishing. Across the cases, there is also a trend of creating ideational, discursive and technical links to state and international-based norms and institutions of fisheries management. The eco-certification approaches differ, however, in terms of scalar emphasis and social development emphasis.

From a Coxian perspective, eco-certification formations can also be distinguished into three contrasting strategic governance models of development (Reed and Mukherjee-Reed, 2012): neoliberal, embedded liberal, and alter-globalization. The programs examined below tend to fall between neoliberal and embedded liberal governance and development models. None of the programs currently engage in strong alter-globalization movements that might form the basis of a progressive counter-hegemonic movement.

\section{Analysis: Explaining the Emergence and Proliferation of TBG in Fisheries}

In the 1990s, in response to the perceived failure of international and national fisheries management, environmental non-governmental organizations (NGOs) and industry collaborators pioneered the development of voluntary market-based instruments to encourage change in buyers' or consumers' decisions and in fishing practices (Gulbrandsen 2010; Kalfagianni and Pattberg 2013). While a plethora of eco-certification initiatives have emerged in fisheries (Parkes et al. 2010), the starting point for most analyses of TBGI in the fisheries sector is the Marine Stewardship Council (MSC). Created in the late 1990s through a partnership between Unilever and the WWF, the MSC's integrated third-party certification, eco-labeling, and traceability program has become the most influential TBG initiative in the sector by securing commitments from large North American and European buyers (e.g. retailers and food service companies) to source MSC-certified seafood (Ponte 2012). By 2017, over 300 fisheries in more than 30 countries, accounting for about $10 \%$ of the world's wild capture harvest, were certified to the MSC's standard for 'sustainable and well-managed' fisheries (MSC 2017). However, new certification, ecolabeling, and traceability programs have proliferated in the wake of the rise of the MSC, particularly in the late 2000s and early 2010s. While a wide range of small and large producers have enrolled in MSC certification, with geographic concentration in the Global North, the MSC's fragile relationship to political economies of production facilitated territorial and ethical eco-certification counter-movements.

Four production-related factors, including issues involving the interaction between social forces of production and the $\mathrm{MSC} /$ global eco-certification formation, have contributed to the proliferation of territorial and ethical eco-certification initiatives. The first two factors concern the relationship between the MSC standard and political economies of production. First, the lack of sensitivity to existing national fisheries management contexts provides some of the impetus for producers and their state and non-state sponsors embedded in particular jurisdictions to resist the MSC and initiate alternatives that better suit 
their interests and aspirations (Foley and Havice 2016; Potts et al., 2016). Unlike the MSC, the Forest Stewardship Council (FSC) mandates the development of context-sensitive national or subnational standards that are consistent with the FSC principles and criteria. This grants a measure of authority and legitimacy to local initiatives and political economies (Auld and Cashore 2012). The MSC, however, relies on strategic outreach offices to interact with state management regimes and producer interests, with no formal incorporation of national contexts in its standard-setting or institutional designs.

Second, the MSC's standard for sustainable and well managed fisheries does not include principles and criteria related to social development. It is focused on ecological principles and criteria, with an emphasis on assessing target fish stock health and fisheries' impacts on ecosystems. It does not cover human rights, labour rights, employment conditions and benefits, or workers' health and safety (Potts et al., 2016: 85). Nor does it incorporate economic indices such as complying with local minimum wage laws, paying workers a living wage, or paying producers a premium over the conventional price of a product (Potts et al., 2016: 89). The MSC also has no institutional mechanism to distinguish between models of production. Unlike 'shade coffee' labels and similar certification systems (Golden et al. 2010), MSC certification and labeling do not provide consumers with information about whether the fish was caught by large industrial fisheries or small-scale fisheries; nor does the MSC distinguish fishing technologies and methods. This is a primary motivation for various producer-oriented social forces of production (e.g. small scale fisheries and grassroots NGOs) to engage in certification initiatives that endorse alternative modes of production.

The third and fourth factors-lack of material rewards and equity in access-focus on the social development consequences of certification for producers. As for the third factor, as noted above, the MSC does not include a direct benefit mechanism such as requiring buyers to pay fishers a price premium to generate economic rewards for certified producers. Some fisheries have received price premiums as a result of market changes, others have not (Morgan 2004; Mathew 2011), while for others the impact of certification on price change remains unclear relative to other factors (Roheim et al. 2011). Where price premiums exist, they are typically captured by retailers, who do not pass them along to producers (Asche et al. 2015: 90; Potts et al. 2016: 149). MSC certification can provide producers with a point of difference for product differentiation, which can in theory improve fishers' position relative to competitors (Morgan 2004; Roheim and Seara 2009), but advantages of differentiation are often lost as competitors become certified (Goyert et al. 2010; May 2012). At the level of production, evidence suggests that it is not the promise of material rewards but the threat of losing access to existing-mainly North American and European-retail markets that has driven much of the early producer interest in MSC certification. Certification can help fisheries access new markets, but it is more commonly sought to maintain access to existing markets controlled by big buyers such as retailers and food service companies that adopt purchasing policies requiring suppliers to have certification (Roheim and Seara 2009; Goyert et al. 2010; Potts et al. 2011).

Finally, and related, for producers, a lack of direct economic rewards from MSC certification is particularly problematic relative to costs of achieving and maintaining certification. While the MSC has attempted to make its certification system relevant and more accessible to small-scale fisheries, particularly those in developing countries, the direct and indirect costs of certification remain a major problem from the producers' perspective. The financial and human resource demands of acquiring and maintaining MSC certification suggest that a relatively high level of capacity is required for marginalized producers to engage in the program. External financial support for small-scale producers will likely remain a common feature in MSC certification as it has for FSC certification (Tikina et al. 2010; Parkes et al. 2010). Larger-scale industrial producers have scale advantages and often have larger data sets that are critical in certification assessments (Potts et al. 2011: 62), but even they remain concerned about certification costs (Foley and Havice 2016). A result is that producers often put pressure on states to support the material costs of acquiring and maintaining certification, thus generating interactions with states. Nevertheless, in 
the absence of more equitable access, initiatives such as the MSC "may well be leading to deeper isolation of many of the poorest would-be providers to international markets" (Potts et al., 2016: 150).

The stark contrast between a key rationale for MSC certification - that producers will benefit and be rewarded for sustainable practices - and the actual problematic outcomes of certification is indicative of more fundamental contradictions in global elite justifications for market-based interventions as empowering marginalized groups (Carodenuto and Cashore, this volume). This is partly why the MSC can be understood as relying on and reinforcing a neoliberal model of governance and development. The MSC's model of implementation and development is characterized by a strong commitment to market forces. Ideationally, it places faith in the neoliberal values of the market, individualism (with consumers as key agents), NGO-corporate partnerships, and devolution of authority (Konefal, 2012). The MSC's tenuous relationship to principles and outcomes of social development is a primary cause for the emergence of ethical eco-certification initiatives that seek to alter the terms and conditions under which some producers interact with the global economy.

\section{Territorial Eco-certification Formations}

The discussion above highlighted the MSC's lack of formal engagement with national fisheries production and management contexts. Despite this failure, in some situations, internal relations between producers and states are being adjusted to the global market imperatives of the MSC (Gale and Haward 2011; Foley 2013; Gulbrandsen 2014) and of sustainability verification and assurance more generally. For other situations (sometimes simultaneously), new territorial eco-certification formations are emerging as social forces of production resist the MSC and incorporate global market norms and institutions into their domestic or local strategies (Foley and Havice 2016). By territorial eco-certification, this analysis refers to a process similar to what Cox theorized as the internationalization of the state, whereby national policies and practices have been adjusted to the exigencies of the world economy (Cox, 1987: 253). But rather than focus on state institutions, this analysis focuses on external pressures and realignments of internal power relations between producers and states in the development of territorial but not necessarily state administered eco-certification.

At the supra-national scale, an example includes the unsuccessful Nordic eco-certification initiatives initiated while the MSC was under development in the late 1990s (Gulbrandsen 2009). Other new national and sub-national eco-certification initiatives have been institutionalized since 2007, in part because of the absence of local flexibility in MSC standard definition and development (Potts et al. 2016: 108). These include Marine Eco-Label (MEL) Japan, which was established in 2007; the Iceland Responsible Fisheries (IRF) eco-label and certification program, which was developed between 2007 and 2009; the Alaska Responsible Fisheries Management (RFM) Certification program, which was created in 2010; and a Canadian pilot project that was initiated in 2011 but failed to materialize (Foley and Hébert 2013; Foley and Havice 2016). All of these programs were motivated by influential and relatively powerful domestic producer associations' interests in developing an alternative to the MSC so as to reassert control over the regulatory relations of production, to enhance control over communication of production and regulatory practices, and to assert a territorial brand of eco-certification (Foley and Havice 2016). None of these programs are administered by governments, however.

Yet interactions with state and international ideas and institutions are critical to each initiative. The state interacts with and facilitates the development of each by supporting the establishment of programs, providing the institutional setting through which programs are established, providing stakeholder representation on new programs, and providing research and technical capacity (Foley and Havice 2016). Internationally, all established initiatives are designed to meet the specifications outlined in the United Nations Food and Agriculture Organization (FAO) Code of Conduct for Responsible Fisheries 
(FAO Code of Conduct) (FAO, 1995) and Guidelines for Ecolabelling of Fish and Fishery Products from Marine Capture Fisheries (FAO Guidelines) (FAO, 2005). Thus, these initiatives are not only embedded in territorial social relations of production but also in international governance norms and institutions, demonstrating the deep interactions among social forces of production, state-civil society complexes and world order spheres in the territorial eco-certification movement (Foley 2017).

While territorial eco-certification challenges the MSC, most existing cases nevertheless currently constitute neo-liberal models of governance and development that share important similarities with the MSC. Like the MSC, these initiatives focus largely on stock-centric and ecosystem notions of sustainable or responsible fishing. Like other forms of non-state and intergovernmental standardization (Wood 2012), both the MSC and most territorial eco-certification initiatives are devoid of substantive social principles and criteria that might support social development purposes. Like the MSC, moreover, alternatives developed at national and subnational levels also hope that compliance with, and transparency of, the sustainable and responsible fishing messaging enabled by certification and labeling standards will afford producers advantages through market forces.

\section{Ethical Eco-Certification Formations}

Unlike the fair trade certification movement, fisheries certification was not born out of a movement for social justice. While certified fair trade farming movements gained momentum as a development strategy for small-scale Southern producers rooted in North-South trade solidarity, the MSC developed a narrow focus on environmental sustainability (Boström et al. 2015). Although social issues have not been a major driver in seafood standards, particularly in the wild caught sector (Potts et al. 2016: 87), a number of eco-certification initiatives have emerged in the Global North in the early 2010s in the wild capture sector that seek to empower structurally disadvantaged producers in both the Global North and the Global South.

For the creators of some emerging eco-certification initiatives, standards and principles of sustainable fishing ought to include producer-oriented economic and social dimensions of sustainability. For example, in 2007, Naturland announced its intention to develop a standard designed to improve the livelihoods of fishers anywhere in the world (Auld 2014: 212). Its current standard includes social responsibility provisions, including those for human rights, freedom to accept or reject employment, freedom of association and access to trade unions, children's rights, health and safety, and general employment conditions (Naturland 2015, 2016). Fair Trade USA announced plans to create the first Fair Trade Capture Fisheries Standard in 2014 to remedy the absence of social criteria in fisheries certification. It aims to incorporate social accountability and industrial health and safety requirements and will be limited to small-scale, artisanal fisheries (Fair Trade USA 2014). Another initiative released in 2014, the Artysanal standard and label, is also limited to artisanal, coastal, and smaller scale fisheries. This Francebased initiative distinguishes fishing methods and technologies and includes social and economic considerations (Artysanal 2014). These certification programs promote specific ethics of production with the aim to distinguish, recognize and reward particular social relations of production and to empower structurally disadvantaged social forces of production.

A related approach, not formally involving certification, makes the social relations of production visible through independent traceability standards. New collaborations between small-scale producers and NGOs have also emerged to endorse not only specific modes of production but also groups and individuals who engage in small-scale production methods. In an effort to raise its profile, for example, the Artysanal program collaborated with the ThisFish traceability program, which is administered by the NGO EcoTrust Canada (ThisFish 2014). This program uses a fish tagging and tracking system to enable consumers to learn about who caught the fish they buy and to communicate information to individual 
harvesters through a website. EcoTrust shares the Artysanal program's triple bottom line approach with a mission around integrating economic, social and environmental values and seeks to explore ways to empower producers to extract more value out of supply chains.

These ethical eco-certification initiatives have limited interactions with states but substantial interactions with international (non-state and state-based) ideas and institutions. Examples of interactions with the state include Artysanal standard's decision not to define small-scale fisheries but instead to rely on the definitions of particular jurisdictions where fisheries operate. Another is the Fair Trade USA standard's requirement of compliance with national law and local legislation as a minimum baseline (Fair Trade USA 2014). Initiatives also interact with non-state and international institutions. One example of interaction with non-state institutions is provided by Naturland, a German-based organic certifier that is accredited by the International Foundation for Organic Agriculture (IFOAM). Fair Trade USA represents another example: some of its environmental criteria will be based on MSC criteria, and fisheries that are already MSC-certified will automatically pass certain parts of the assessment focusing on ecological criteria. The France-based Artysanal program was developed through an international collaboration between SMART Association, the World Forum of Fish Harvesters and Fish Workers (WFF), and Eurofins Certification, the authorized certification body for Artysanal. ThisFish administers a traceability data standard but it does not develop its own rules around the sustainability of fisheries or seafood. It instead shows eco-ratings of various other programs such as the MSC, Ocean Wise, SeaChoice and Seafood Watch on its system as a way to communicate environmentally relevant information to buyers such as retailers, chefs, and consumers.

Like the MSC and territorial eco-certification initiatives, interactions with international institutions such as the FAO and the International Organization for Standardization (ISO) appear important for ethical eco-certification initiatives. The Fair Trade USA capture fisheries standard claims that its standard follows the FAO Code of Conduct, the FAO Guidelines, and a number of International Labour Organization conventions (Fair Trade USA 2014). The Artysanal Standard claims it is distinct from other prominent labels by integrating environmental, economic, and social criteria as recommended in the UN FAO Code of Conduct. The ThisFish program interacts with international norms by distinguishing itself from other standards, including a new ISO standard (ISO 12875) for the traceability of finfish released in 2011 and the European Union's "catch certificate" regulation requiring validation from governments of exporting countries that imported seafood came from a legal fishery (ThisFish 2012). Like the MSC and in contrast to territorial eco-certification initiatives, these ethical eco-certification initiatives are also internationalized in the sense of supporting producers from different jurisdictions. The Fair Trade USA approach is limited in that it will assess and certify only US companies and their international suppliers. The Artysanal standard is more ambitious as it was created to "drive development in the fishing industry towards responsible fishing from artisanal, small-scale, coastal fisheries worldwide" (Artysanal 2014: 14). Its aim is "to become internationally recognized and it is open to any fishery (both from developing and developed countries) that complies with the related specification requirements" (Artysanal 2014: 14). Thus, while ethical eco-certification initiatives are oriented towards supporting specific social relations of production, the programs interact with international and transnational institutions and norms. And although ethical eco-certification initiatives interact less with states than territorial eco-certification initiatives, the varied interactions with state-civil society and, more importantly, world order spheres of activity suggest that Cox's 'production and power' approach has analytical and explanatory value.

These ethical eco-certification initiatives have fundamental goals to transform power relations in the social and economic arenas so as to render visible, and provide more opportunities for, structurally disadvantaged producers and workers. The initiatives embrace an approach more attentive to questions of social development for marginalized producers and promote alternative versions of what constitutes relevant knowledge about production processes and how and to whom to communicate that knowledge (Parlee and Wiber 2011). However, while these approaches explicitly privilege structurally disadvantaged 
producers, they also contain elements of a neo-liberal model of governance and development by taking the prevailing consumption structures as given and placing substantial faith in the capacity and willingness of institutional and corporate buyers and consumers to deliver material value and benefits to producers. Like both the MSC and territorial eco-certification approaches, these ethical eco-certification initiatives place faith in market mechanisms and do not have the capacity for, or a strategy to achieve, structural transformation. While Fair Trade USA includes an institutional mechanism to require buyers to pay fishers a fair trade premium, the impact of the premium depends on the fluctuations of market-driven prices. There is no mechanism for general structural change or an alternation of prevailing power relations. Each ethical eco-certification initiative shares the MSC's faith in the power of transparency and market mechanisms. The programs, in other words, are more akin to embedded liberalism than alterglobalization.

\section{Discussion: Transnational Business Governance Interactions}

This section reflects on the implications of the analysis above for the 'dimensions of interaction' in the TBGI framework, in particular drivers and shapers, mechanisms and pathways, characters and effects of interaction (Eberlein et al. 2014). In terms of drivers and shapers of interactions, a key feature driving proliferation and competition in the fisheries sector is the effort of social forces of production to re-embed political economic interests and values in eco-certification initiatives and in trade relations more generally. This embedding emphasizes specific and competing political economies of ecocertification, which I have theorized as territorial and ethical eco-certification initiatives. These trends demonstrate not only how industry characteristics drive key aspects of TBGI in the fisheries sector, but also how multi-faceted and contested producer interests specifically drive competition and proliferation. The distinction between large-scale industrial and small-scale artisanal fisheries, though complex and blurred in many contexts, provides a key wedge in the global politics of fisheries certification and distinguishes ethical eco-certification initiatives from both the MSC and most territorial eco-certification programs.

Cultures, discourses, mentalities, epistemic communities and ideational factors also drive TBGI in the sector. The cultural politics of neo-liberal globalization and faith in market mechanisms constitute a meta-ideational and institutional 'world order' driving force that operates across all spheres of interaction and in all eco-certification initiatives. The development of some territorial eco-certification initiatives was driven by deeply cultural and nationalistic politics of nationally and sub-nationally embedded seafood producers. For ethical eco-certification initiatives, we observe a different set of cultural discourse committed to small-scale, artisanal fish workers who are often situated in vulnerable rural coastal communities where there are few economic development alternatives to fish production.

Mechanisms and pathways of interaction include various tools and techniques of governance. The MSC, territorial and ethical eco-certification formations constitute hybrid governance through which nonstate and state norms, practices, tools and techniques are enrolled in influencing conditions of production and market access. Rule referencing and conditional rule referencing were observed across cases and scales of interaction as various initiatives seek to enhance legitimacy, capacities and symbolic resources. The FAO is the most significant international rule reference point.

In terms of the character of interactions, we also observe competition, coordination, and cooptation, often simultaneously. We observe competition for authority over key terms such as who and what defines sustainable and responsible fisheries. We also observe competition over regulatory turf, reputation and legitimacy in the rise of territorial eco-certification initiatives. Territorial eco-certification initiatives created as distinct alternatives to the MSC nevertheless adopt policies and procedures shared with the MSC, with most claiming compliance to UN FAO fisheries management norms, many of which 
were developed before the emergence of the MSC. Ethical eco-certification initiatives coordinate by "carving out" niches (Eberlein et al. 2014: 22) in the sector as they seek to fill a perceived gap in social principles and criteria. Competition and coordination also exist together, which is particularly salient with the trend across the cases to incorporate UN FAO norms and guidelines. This trend is important evidence of the value of applying Cox's approach, which expects that the most promising hegemonic or counterhegemonic strategies will integrate ideas and institutions of the social forces of production, state-civil society complexes and world order.

The effects of interactions within and between eco-certification formations are both competitive and mutually reinforcing. Patterns of emulation around the FAO guidelines on eco-labeling enhance legitimacy and credibility in the increasingly competitive field (Foley and Havice 2016). The continuities of market-orientation have also created a mutually reinforcing legitimacy dynamic (Meidinger 2009: 249) around faith in the idea that voluntary eco-certification initiatives will generate win-win governance and economic outcomes. However, even initiatives that include more explicit principles of social sustainability and responsibility for producers do not necessarily have a greater direct impact on social development. As Boström et al. argue with reference to an inquiry into the concept of social sustainability in standards more broadly, "even in the most contrasting case-Fairtrade-social sustainability is shaped and narrowed through processes of bureaucratization, translation, and adoption into local settings" (Boström et al. 2015: 151). Ultimately, they conclude, "integrating the social and the environmental in policy, administration, and management will require a long-term learning process" (Boström et al. 2015: 152). The impacts of proliferation and interaction ultimately remain an open question, though the patterns of interaction and change do not appear fundamentally transformative at present.

\section{Conclusion: Towards Counter-Hegemonic Movements?}

Producer interests and identities are not homogenous. The proliferation of territorial and ethical eco-certification initiatives in the last decade reflects not only the agency and interests of producers, but also the varied relations and interests of production and divergent producer visions of development. Territorial and ethical eco-certification initiatives reflect different strategies to distinguish and reward different political economies of production and different models of (sustainable or responsible) development. The strategies of governance and development constitute, in effect, differing visions not just of production but also of social reproduction: the relationship between the human and ecological conditions of livelihood and survival and the historical structures that depend on those social and ecological conditions (Bakker and Gill 2003).

While the integration of producer interests with new eco-certification initiatives can be interpreted as enhancing participatory governance through local or 'stakeholder' ownership, it also creates competition, fragmentation and confusion (Potts et al., 2016: 109). The general response of each alternative is to integrate internationally recognized norms and institutions into eco-certification, particularly the fisheries management principles and eco-labeling guidelines of the FAO. By translating Cox's 'production and power' approach to an analysis of these dynamics, we can see that territorial and ethical eco-certification initiatives compete with the MSC in terms of representing and recognizing different social relations of production, but share the MSC's commitment to world order norms and institutions such as the FAO and, more generally, to neo-liberal forms of governance and development.

The relationship between fisheries eco-certification and hegemony is ambiguous. Like the forestry eco-certification movement, fisheries eco-certification initiatives are products of the historical forces of neoliberal global political economy. The FSC has been conceptualized as a product of neo-liberal world order but with counter-hegemonic potential relative to eco-certification alternatives developed collaboratively by industrial producers and states (Bloomfield 2012). Its counter-hegemonic potential lies 
mainly in its institutional structure as an open multi-stakeholder forum (Bloomfield 2012) and in its inclusion of social principles and criteria. The MSC, however, uses a more closed multi-stakeholder institutional structure and lacks a social category of principles and criteria (Gulbrandsen 2010). Territorial eco-certification initiatives tend to share the MSC's core focus on ecological sustainability, while ethical eco-certification initiatives tend to offer competing visions of (sustainable or responsible) development that seek to empower structurally disadvantaged producers and workers. As currently constituted, the most significant potential of ethical eco-certification initiatives is their ability to influence ideas (e.g. values and principles of sustainable or responsible fisheries) and institutional contexts in global fisheries governance debates. This influence might help shift policy debates away from conceptions of sustainable and responsible fisheries consistent with a neo-liberal globalization model of development to conceptions that challenge existing power structures by including ethical and social justice considerations. It might help shift the agenda, in other words, away from neo-liberal models of governance and development towards embedded liberal or alter-globalization models of governance and development. However, while ethical eco-certification initiatives can ideationally and institutionally challenge prevailing power relations that privilege industrial producer and corporate interests, the counter-hegemonic potential of existing approaches is significantly constrained by structural and material disadvantages of the initiatives and by the passive approach of voluntary, market-oriented eco-certification.

To be counter-hegemonic in the sense used by Cox, initiatives will likely need to integrate social relations of production with state and world order ideas and institutions in a way that can meaningfully challenge the prevailing power relations and systematically support structurally disadvantaged producers. An important constraint, a Coxian perspective tells us, is that states and international organizations will tend "to develop governance strategies based upon particular types of economic development models that reflect the interests of the actors that constitute their basis of support" (Reed and Mukherjee-Reed, 2012: 369). This partly explains why existing territorial eco-certification initiatives tend to reflect the interests of large, industrial-dominated national or subnational producer associations (Foley and Havice 2016) and why many states tend to support domestic industry efforts to achieve MSC certification. Another constraint includes 'new constitutionalist' institutions like the World Trade Organization, which facilitate market-driven and 'trade-friendly' voluntary mechanisms of governance but make it difficult for governments to formally endorse or institutionalize voluntary standards (Gill 1995; Gill 1998). It is important to enhance our understanding of these constraints through further research in order to understand the challenges of, and opportunities for, supporting eco-certification as a counter-hegemonic movement.

What is needed is a new historic bloc of collaborations (or public-private partnerships) between political and civil society that can overcome these constraints to form the basis of a new global fisheries governance regime committed to a form of sustainable and responsible development that meaningfully includes social and economic principles and that generates material protections and security for disadvantaged and vulnerable producers and workers. Two paths to such a counter-hegemonic ecocertification movement are conceivable from a Coxian perspective. A first might involve the MSC transforming its approach by integrating social standards of sustainability and engaging more formally with state-civil society complexes and international institutions (such as the FAO) as a strategy for expanding embedded liberalism in fisheries. Since its inception, some producers and civil society actors have pressured the MSC to incorporate social principles into its standard, but the MSC has resisted such moves. While industry actors continue to pressure the MSC to incorporate social dimensions of sustainability into its standard, some producers are divided on the issue of whether and how to engage the social question (Kearns 2017). For this reason and given that the MSC is already deeply embedded in industrial and corporate structures, even if the MSC incorporates social principles into its approach, it will more likely develop an approach that remains neo-liberal or a soft embedded liberal approach. 
A second, more bottom-up approach might involve the strategic coalescing of an ethical ecocertification initiatives (most of which currently operate transnationally) with a territorial eco-certification approach. For this approach to challenge the prevailing power relations in the global political economy of fisheries, social movements from civil society, including producers and progressive environmental NGOs, will need to foster new identities of shared interests between seafood workers and transnational economic interests, from financial and trading interests to service workers and consumers. To develop further hegemonic potential, additional political action and organization within nation-state and international institutions and structures will then be required to institutionalize an integrated and ethically based alter-globalization model of governance and development.

\section{Acknowledgements}

The author would like to thank Stepan Wood, Derek Hall, and Sophia Carodenuto for helpful comments and suggestions on earlier drafts of this paper. This research was supported by the Social Sciences and Humanities Research Council of Canada.

1 This adaptation draws parallels to a recent study by Westermann, who adapts the neo-Gramscian approach to the study of migration systems (Westermann 2013). 


\section{References}

Artysanal (2014). "Artysanal ${ }^{\circledR}$ Standard: For artisanal, coastal and small-scale fisheries," SMART Association. Montélimar, France.

Asche, F., Larsen, T.A., Smith, M.D., Sogn-Grundvåg, G., and Young, J.A. (2015). "Pricing of eco-labels with retailer heterogeneity," Food Policy, Vol. 53: 82-93.

Auld, G. (2012). "The Marine Stewardship Council," in Reed, Utting, Mukherjee-Reed (Eds.). Business regulation and non-state actors: Whose standards? Whose development? New York: Routledge.

Auld, G. (2014). Constructing private governance: The rise and evolution of forest, coffee, and fisheries certification. New Haven: Yale University Press.

Auld, G. and Cashore, B. (2012). "The Forest Stewardship Council," in Reed, Utting, Mukherjee-Reed (Eds.). Business regulation and non-state actors: Whose standards? Whose development? New York: Routledge, pp. 134-147.

Auld, G. and Cashore, B. (2013). "Mixed signals: NGO campaigns and non-state market- driven (NSMD) governance in an export-oriented country," Canadian Public Policy, Vol. 39: 143-156.

Bakker, I. and Gill, S. (2003). Power, production and social reproduction: human in/security in the global political economy. Basingstoke, Hampshire: Palgrave MacMillan.

Bloomfield, M.J. (2012). Is forest certification a hegemonic force? The FSC and its challenges. Journal of Environment \& Development, Vol. 21(4): 391-413.

Boström, M. Vifell, A.C., Klintman, M., Soneryd, L., Hallström, K.T., and Thedvall, R. (2015). “Social sustainability requires social sustainability: Procedural prerequisites for reaching substantive goals," Nature and Culture, Vol. 10(2): 131-156.

Büthe, T. (2010). Global private politics: A research agenda. Business and Politics, Vol. 12(3).

Cashore, B., Auld, G., and Newsom, D. (2004). Governing through markets: Forest certification and the emergence of non-state authority. New Haven, CN: Yale University Press.

Cox, R.W. (1983). "Gramsci, Hegemony, and International Relations: An Essay in Method," Millennium: Journal of International Studies, Vol. 12 (Summer), pp. 162-175.

Cox, R.W. (1987). Production, Power, and World Order. Columbia: Columbia University Press.

Cox, R.W. (1996). "Social Forces, States, and World Orders," In Approaches to World Order, Robert W. Cox with Timothy J. Sinclair. New York, NY: Cambridge University Press.

Cox, R.W. with M.G. Schechter (2002). The Political Economy of A Plural World: Critical Reflections on Power, Morals and Civilization. London: Routledge.

Eberlein, B., Abbott, K.W., Black, J., Meidinger, E., and Wood, S. (2014). "Transnational business governance interactions: Conceptualization and framework for analysis," Regulation \& Governance, Vol. 8(1): 1-21.

Fair Trade USA (2014). Fair Trade USA Capture Fisheries Standard: Draft Version 1.0. Fair Trade USA. Available at http://fairtradeusa.org/sites/all/files/wysiwyg/filemanager/standards/FT USA Capture Fisherie s Standard.pdf

FAO (2005). The FAO Guidelines for the Ecolabelling of Fish and Fisheries Products from Marine Capture Fisheries. Rome: FAO.

Foley, P. (2013). "National government responses to Marine Stewardship Council (MSC) certification: insights from Atlantic Canada," New Political Economy, 18(2): 284-307.

Foley, P. (2017). "The territorialization of transnational sustainability governance: production, power and globalization in Iceland's fisheries," Environmental Politics, 26(5): 915-937.

Foley, P. and Havice, E. (2016). "The rise of territorial eco-certifications: New politics of transnational sustainability governance in the capture fisheries sector," Geoforum, Vol. 69 (February): pp. 24-33. 
Foley, P., and Hébert, K. (2013). "Alternative regimes of transnational environmental certification: governance, marketization, and place in Alaska's salmon fisheries," Environment and Planning $A$, 45(11): 2734-2751.

Gale, F. (2014). "Australian forest governance: A comparison of two certification schemes," Australian Journal of Environmental Management, Vol. 21(4): 396-412.

Gale, F. and Haward, M. (2011). Global commodity governance: state responses to sustainable forest and fisheries certification, (Houndmills, Basingstoke, Hampshire: Palgrave Macmillan).

Gill, S., (1995). 'Globalisation, market civilisation, and disciplinary neoliberalism.' Millennium: Journal of International Studies. Vol. 24(3): 399-423.

Gill, S., (1998). 'New constitutionalism, democratisation and global political economy.' Pacifica Review. Vol. 10(1): 23-38.

Golden, J.S., Dooley, K.J., Anderies, J.M., Thompson B.H., Gereffi G., and Pratson L., (2010). "Sustainable Product Indexing: Navigating the Challenge of Ecolabeling," Ecology and Society, Vol. 15, No. 3.

Goyert, W., Sagarin, R. and Annala, J. (2010). "The promise and pitfalls of Marine Stewardship Council certification: Maine lobster as a case study," Marine Policy, 34 (5), pp. 1103-1109.

Gulbrandsen, L. (2009). "The emergence and effectiveness of the Marine Stewardship Council," Marine Policy, 33: 654-660.

Gulbrandsen, L. (2010). Transnational environmental governance: The origins and effects of the certification of forests and fisheries. Cheltenham, England: Edward Elgar.

Gulbrandsen, L. (2014). "Dynamic governance interactions: Evolutionary effects of state responses to non-state certification programs," Regulation \& Governance, 8(1): 74-92.

Hallström, T., and Boström, M. (2010). Transnational multi-stakeholder standardization: organizing fragile non-state authority. Cheltenham: Edward Elgar.

Havice, E., and Iles, A. (2015). "Shaping the aquaculture sustainability assemblage: Revealing the rulemaking behind the rules," Geoforum, 58: 27-37.

Kalfagianni, A. and Pattberg, P. (2013). Fishing in muddy waters: exploring the conditions for effective governance of fisheries and aquaculture," Marine Policy, 38, pp. 124-32.

Kearns, M. (2017). Urged by industry, MSC weighs adding social sustainability standards.

SeafoodSource.com. Retrieved from: https://www.seafoodsource.com/news/environmentsustainability/how-should-certifiers-approach-social-sustainability--sanford-ceo-top-industrypanel-weighs-

in?utm source=informz\&utm medium=email\&utm campaign=newsletter\&utm content=newsl etter

Konefal, J. (2012). "Environmental movements, market-based approaches, and neoliberalization: A case study of the sustainable seafood movement," Organization \& Environment, 26(3): 336-52.

Mathew, S. (2011). 'The costs of certification.' SAMUDRA Report, March, No. 58: 41-45. Retrieved from http://www.icsf.net/icsf2006/uploads/publications/samudra/pdf/english/issue 58/art09.pdf

May B. (2012). "What Alaska's pullout tells us about the Marine Stewardship Council", retrieved from http://www.robertsbridgegroup.com/what-we-think/alaska-pullou/. Accessed on 1 October 2012.

Morgan, G. (2004). "Report into the Marine Stewardship Council Re-certification of the Western Rock Lobster Fishery," Prepared for the Western Australian Fishing Industry Council (WAFIC), 27 August.

MSC (2017). "MSC in numbers," Marine Stewardship Council, London Retrieved from:

https://www.msc.org/global-impacts/key-facts-about-msc. Naturland (2015). "Naturland: Welcome to Naturland". Available at: http://www.naturland.de/en/naturland/what-we-do/naturlandseafood/sustainable-capture fishery.html 
Naturland (2016). "Naturland Standards for Sustainable Capture Fishery," Version 05/2016. Germany. Retrieved from www.naturland.de.

Parkes, G., Young, J.A., Walmsley, S.F., Abel, R., Harman, J., Horvat, P., Lem, A., MacFarlene, A., Mens, M. and Nolan, C. (2010). "Behind the signs - A global review of fish sustainability information schemes," Reviews in Fisheries Science, 18(4), pp. 344-356.

Parlee, C.E. and Wiber, M. (2011). "Who is governing food systems? Power and legal pluralism in lobster traceability," The Journal of Legal Pluralism, 43, pp. 121-148.

Ponte, S. (2012). "The Marine Stewardship Council (MSC) and the making of a market for 'sustainable fish," Journal of Agrarian Change, 12(2-3): 300-315.

Potts, T. And Haward, M. (2007). 'International trade, eco-labelling, and sustainable fisheries-recent issues, concepts and practices.' Environment, Development and Sustainability. Vol. 9: 91-106.

Potts, T., Brennan, R., Pita, C., and Lowrie, G. (2011). Sustainable seafood and eco-labelling: the Marine Stewardship Council, UK consumers, and fishing industry perspectives. SAMS Report: 270-211. Scottish Association for Marine Science.

Potts, J., Wilkings, A., Lynch, M., and McFatridge, S., (2016). 'State of sustainability initiatives review: standards and the blue economy. Winnipeg: International Institute for Sustainable Development (IISD). [online] URL: http://www.iisd.org/library/state-sustainability-initiatives-review-standardsand-blue-economy

Raynolds, L.T., and Wilkinson, J. (2007). "Fair Trade in the agriculture and food sector: analytical dimensions," In L.T. Raynolds, D.L. Murray, \& J. Wilkinson (Eds.), Fair Trade: the challenges of transforming globalization (pp. 33-48). London and New York: Routledge.

Raynolds, L.T., Murray, D., Heller, A. (2007). "Regulating sustainability in the coffee sector: a comparative analysis of environmental and social certification and labeling initiatives," Agriculture and Human Values, 24(2): 147-163.

Reed, D. and Mukherjee-Reed, A. (2012). "From non-state regulation to governance? Shifting the site of contestation," in Reed, Utting, Mukherjee-Reed (Eds.) Business regulation and non-state actors: Whose standards? Whose development? New York: Routledge.

Roheim, C. and Seara, T. (2009). Expected benefits of fisheries certification: results of a survey of MSC fisheries clients. URI Sustainable Seafood Initiative, Rhode Island, USA. [online] URL: http://seagrant.gso.uri.edu/sustainable seafood/pdf/Fisheries\%20Client\%20Report Final.pdf.

Roheim, C., Asche, F., Insignares, J. (2011), "The elusive price premium for ecolabelled products: Evidence from seafood in the UK market," Journal of Agricultural Economics, 62(3): 655-668.

Smith TM, and Fischlein, M. (2010). "Rival Private Governance Networks: Competing to Define the Rules of Sustainability Performance," Global Environmental Change, Vol. 20, 511-522.

ThisFish (2012). "ThisFish Traceability Data Standard 1.0: Draft Document for Public Consultation," Ecotrust Canada, June 19, Retrieved from http://thisfish.info/generic/article/37/

ThisFish (2014), "World's first small-scale fishery certification uses ThisFish traceability," Ecotrust Canada, http://thisfish.info/generic/article/artysanal-iceland/

Tikina, A. V., Innes, J. L., Trosper, R. L., and Larson B. C. (2010). “Aboriginal peoples and forest certification: a review of the Canadian situation," Ecology and Society 15(3):33.

Utting, P. (2012). "Introduction: Multistakeholder regulation from a development perspective," in Reed, Utting, Mukherjee-Reed (Eds.) Business regulation and non-state actors: Whose standards? Whose development? (New York: Routledge).

Westermann, R. (2013). "The neogramscian approach: Using 'critical' theories to explain migration systems," Paper presented at the THEMIS conference, Examining Migration Dynamics: 
Networks and Beyond, University of Oxford, September 24-26. Retrieved from https://www.imi.ox.ac.uk/events/themis-2013/presentations/westermann.pdf

Wood. (2012). "The International Organization for Standardization," in Reed, Utting, Mukherjee-Reed (Eds.) Business regulation and non-state actors: Whose standards? Whose development? (New York: Routledge), pp. 81-94.

Wood, S., Abbott, K., Black, J., Eberlein, B., and Meidinger, E. (2015). "The interactive dynamics of transnational business governance: A challenge for transnational legal theory," Transnational Legal Theory Vol. 6(2): 333-369. 